\title{
Research on Mechanical and Durability Properties of GGBS and Copper Slag Mix Mortar
}

\author{
Velmurugan K, Karthiyaini S
}

\begin{abstract}
Theoretical: Cement is the superb wellspring of ecological impact in cement and mortar making. This is due to parcel of carbon dioxide $\left(\mathrm{CO}_{2}\right)$ emanation. This assignment manages supplanting of bond with GGBS and motion sand with copper slag and $\mathrm{M}$-sand along nanoparticles like Titanium dioxide $\left(\mathrm{TiO}_{2}\right)$ has been incited to enhance the microstructure and increment the compressive first-rate of the mortar. The mechanical and durability research are finished at 7,28 and 56 days and are been contrasted and the not unusual mortar.
\end{abstract}

Watchwords: Copper slag, sturdiness examines, GGBS, Titanium dioxide.

\section{CREATION}

Inside the location of structural constructing, bond is the essential cloth to be carried out in a improvement however the bond that is carried out in advent of mortar and cement has a tremendous impact in contaminating the earth. That is because of parcel of carbon dioxide $\left(\mathrm{CO}_{2}\right)$ outflow from the concrete organizations.

The most awesome approach for looking after this hassle is to discover a desire to supplant bond in mortar making. It's miles positioned that use of waste substances from ventures are prudent definitely as eco-accommodating in nature. This examination manages the supplanting of bond with floor-granulated effect heater slag (GGBS). GGBS is gotten thru fast extinguishing of liquid iron slag from the impact heater with the beneficial useful aid of water, due to its non-infection nature and rapid putting propensity it's miles been considerably executed. Basically the ordinary fines like waterway sand have grew to end up out to be unusual due to increment of urbanization and industrialization, so there emerge the requirement for optional substitution. Copper slag is one of the cutting-edge-day-day waste this is received at some point of copper extraction by using manner of using the usage of purifying system. Numerous to severa one-of-a-kind fill materials it gives typically a lot much less threat to the earth and it likewise improves the scraped spot and effect fine of the mortar. What's greater nanoparticles like Titanium dioxide $\left(\mathrm{TiO}_{2}\right)$ is to be incited to enhance the compressive brilliant of the mortar.

\section{II.LITERATURE SURVEY}

Rami Hawileh et al., [1] check approximately the effect of

Revised Version Manuscript Received on 10, September 2019.

Velmurugan K, Student of final year M.Tech, VIT Chennai, Tamilnadu, India.(Email: vela1995@gmail.com) Building Sciences, VIT Chennai, Tamilnadu, India.
Karthiyaini S, Assistant Professor (Sr.), School Of Mechanical and

the use of floor Granulated Blast-heater Slag (GGBS) as an incomplete substitution to fastener in sturdy pillars. Bars

have been tossed with precise paces of GGBS substitution of zero $\%$, half of of, $70 \%$, and ninety $\%$. Sturdy pillars threw with to $70 \%$ GGBS substitution to bond have acted likewise to shafts thrown with the everyday robust combination without GGBS (0\% GGBS). Using prolonged degree of GGBS substitution to fastener as an lousy lot as $70 \%$ in concrete mixes might be possible within the improvement publicize.

Oner et al., [2] offers an exam on ideal diploma of ground granulated impact heater slag (GGBS) at the compressive amazing of cement. Take a look at cements have been received with the aid of way of the usage of collectively with GGBS through $0 \%, 15 \%, 30 \%$,

Half of of, $70 \%, 90 \%$ and one hundred $\%$. The test effects demonstrates that the compressive exceptional of strong combination containing GGBS increments as the amount of GGBS beautify. Be that as it could, the early age splendid of GGBS cements have become no longer exactly the manage cements. Cause for that is pozzolanic response is mild and the affiliation of calcium hydroxide desires time.

Krishna Rao et al.,[3] tested the effect of GGBS on the mechanical homes and scraped area competition. The compressive exceptional of the examples had been dwindled for 3 days at the same time as GGBS substance progressed. Be that as it is able to, at 7 years vintage days and 28 days the tendencies were drastically higher than manage mixture cement as a extraordinary deal as half substitution of GGBS. Higher GGBS substance has extended the scraped spot opposition of cement.

Alaa Rashad et al.,[4] research using GGBS and CS as an incomplete and whole substitution of feature high-quality widespread in mortars and cements relying on Portland bond (pc). The effects confirmed that usefulness of the mixture faded with increasing GGBS. The incorporation of GGBS up

To $40 \%$ extended scraped spot opposition of cement. The eye

Of CS sand has useful very last results on chloride particle the front and shrinkage.

Ishimaru et al.,[5] researched the impact of using copper slag as a substitution of first-rate trendy at the first-class homes. M25 assessment cement modified into used and checks had been cultivated for numerous ranges of copper slag converting with sand of $0 \%$ to $100 \%$ in bond. The take a look at effects show off that compressive nature of

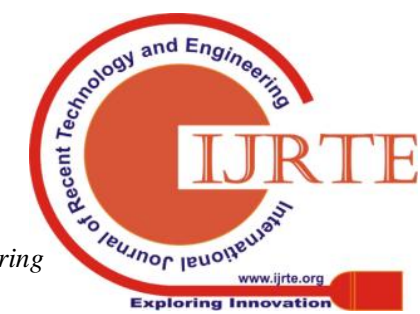


concrete extended through way of way of fifty $5 \%$ at forty $\%$ substitution of terrific regular with the useful aid of copper slag.

Khalifa Al-Jabri et al.,[6] explored the impact of the usage of copper slag as a high-quality contemporary at the houses of mortars and cement. Numerous mortar and stable mixes have been tossed with awesome ranges of copper slag walking from zero $\%$ to one hundred $\%$ as first-rate preferred that every one mixes with numerous copper slag degrees yielded same or better compressive terrific than that of the control combination. There's a five\% extension in the sturdy thickness, on the equal time as copper slag end up used as a sand substitution, at the same time as the usefulness decorate with an addition in copper slag content material material cloth.

Madheswaran et al.,[7] observed that concrete mortar mixes orchestrated with high-quality desired made up of various degrees of copper slag and sand were long beyond after for use as block artwork mortars and placing. Copper slag can be used for putting of floor substances and horizondal as lots as $50 \%$ via mass of the excellent elegant, and for vertical surfaces, for example, square/block is probably used spherical $25 \%$. Appeared in a special manner almost approximately the manage mixture, for copper slag based without a doubt cement, there can be a improvement within the thickness as plenty as $19 \%$.

Muhd Norhasri et al.,[8] referred to the Nano substances in concrete. Through together with the Nano substances in strong its first-class and durability increments. The scale of Nano materials have to be $500 \mathrm{~nm}$. To decorate the coupling effect and to lower the bond content material fabric ultrafine Nano materials are introduced to the aggregate. He likewise clarifies the points of interest and blessings of making use of Nano materials in concrete.

Mohamed Sadawy et al.,[9] examined that the impact of nano $\mathrm{TiO}_{2}$ on compressive high-quality, bond splendid and consumption behavior of fortification bars. It has been determined that the compressive high-quality, bond superb and intake competition became extended with growing nano- $\mathrm{TiO}_{2}$ upto $1.5 \%$ weight substitution of concrete. Past this nicely worth, the ones residences decline.

Jugal Mistry et al.,[10] reasoned that the fundamental concept the usage of the use of Nano cloth which is probably having massive floor locale is to enhance compressive and flexural satisfactory at early ages, advanced hydration traits and diminished porosity and water maintenance at the equal time as diverged from traditional cementitious cloth.

\section{III.SUBSTANCES}

\section{A. Substances Used}

Concrete: OPC (normal Portland Cement) of assessment fifty 3 has been carried out for this task. The proper gravity of concrete located the use of Le Chatelier tool grow to be seen as 3.15 (No unit).

GGBS: floor-granulated impact heater slag (GGBS) is acquired thru rapid extinguishing of liquid iron slag from the effect heater through water, due to its non-poison nature and rapid putting propensity it's far been generally carried out. Unique gravity of GGBS is seen as 2.805 (No unit). substitution. The effects were given for bond mortars showed

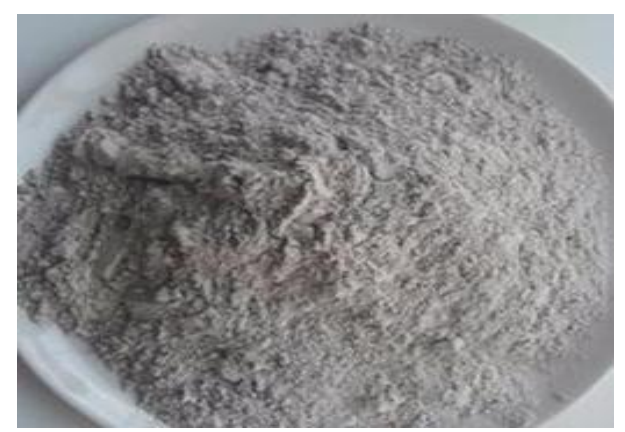

Fig.1 ground-granulated impact heater slag

Copper slag: Copper slag is one of the modern waste this is acquired inside the course of copper extraction by means of utilizing the utilization of purifying strategy.

Not at all like various fill substances it presents pretty bounty a horrendous parcel less hazard to the earth. Totals passing through $1.18 \mathrm{~mm}$ strainer is utilized on this test. Explicit gravity of copper slag is resolved to be four.12 (No unit).

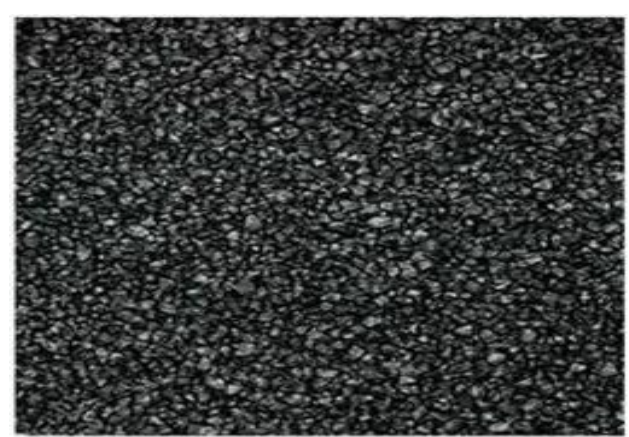

Fig.2 Copper slag

M-sand: artificial sand (M sand) subs for circulate sand for cement and mortar making. Produced sand are received via way of smashing of difficult rock stones. The squashed sand is of cubical form with grounded edges. It's miles washed and carried out as improvement fabric. Totals going via $1.18 \mathrm{~mm}$ strainer is implemented in this undertaking. Specific gravity of artificial sand is visible as 2.61 (No unit).

Titanium dioxide $\left(\mathrm{TiO}_{2}\right)$ : Titanium dioxide is acquainted in concrete all together with decorate the high-quality, decorate the substances mass homes and decrease the outcomes for situation. The size of Nano substances is 500nm..

Superb plasticizer: Conplast sp430 is delivered to the water to enhance the functionality of the mixture.

\section{A. Mixture Proportions}

The mixture extents for the mortar is resolved to be 1:3 (1 section folio : 3 segment high-quality totals) after awesome initial combination.

Water concrete percent is zero.6. Titanium dioxide of $1.5 \%$ is introduced to the mix. Exquisite plasticizer of 0.Sixty five $\%$ is protected..

\section{B. Combination statistics}

The great mixture subtleties are given in table 1 .

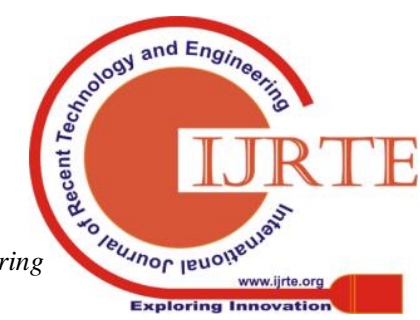




\begin{tabular}{|l|l|l|l|l|}
\hline Mix & Control & Mix 1 & Mix 2 & Mix 3 \\
\hline Cement & $100 \%$ & $80 \%$ & $60 \%$ & $40 \%$ \\
\hline GGBS & - & $20 \%$ & $40 \%$ & $60 \%$ \\
\hline M-sand & $100 \%$ & $60 \%$ & $60 \%$ & $60 \%$ \\
\hline $\begin{array}{l}\text { Copper } \\
\text { slag }\end{array}$ & - & $40 \%$ & $40 \%$ & $40 \%$ \\
\hline
\end{tabular}

Table 1 Mix Details

\section{EXPERIMENTAL WORKS}

\subsection{Ultrasonic Pulse pace test (UPV)} cement thru ultrasonic heartbeat tempo technique consistent with seems to be: 13311 (detail 1) - 1992. The method contains of estimating the hour of motion of a ultrasonic heartbeat going through the mortar being attempted.

nearly higher tempo is gotten on the same time as solid extraordinary is super as some distance as thickness, consistency, homogeneity and so on. The fee foundation is given in desk

\begin{tabular}{|l|l|}
\hline Pulse Velocity $(\mathrm{Km} / \mathrm{s})$ & Quality \\
\hline Above 4.5 & Excellent \\
\hline $3.5-4.5$ & Good \\
\hline $3.0-3.5$ & Medium \\
\hline Below 3.0 & Doubtful \\
\hline
\end{tabular}

Table 2- Velocity criterion for quality grading

\section{Four.1 Compressive top notch check}

The examples of length $70.6 \times 70.6 \times 70.6 \mathrm{~mm}$ are casted and tried through manner of pressure sorting out device after their relieving time of multi day, 28 days, and 56 days. The burden should be carried out grade by grade at the tempo of 140 $\mathrm{kg} / \mathrm{cm} 2$ every moment untill the examples falls flat. Burden on the disappointment remoted by using manner of location of example invigorates the compressive of cement.

\section{Four.2 Tensile exceptional take a look at}

The anxiety of concrete mortar is dictated with the aid of using throwing of checks within the predefined briquette shape regular with

ASTM-C-100 90. After the mortar has been set it's far been water restored. The trying out has been completed on 7 and 28 days. The heap is to be finished at a formally dressed tempo of $35 \mathrm{~kg} / \mathrm{cm}^{2}$.

\section{Three Water ingestion check}

This test end up executed in keeping with ASTM C 642-06 on solidified mortar. Examples of $70 \mathrm{~mm}$ three-d form were range dried at $110 \pm$ five ${ }^{0} \mathrm{C}$ for twenty-four $\mathrm{h}$ and have been gauged. The examples were then dried all once more for twenty- $4 \mathrm{~h}$ and gauged. The cutting-edge gauged values for exams had been analyzed and if the worth indicated over zero. $5 \%$ variety, the examples had been dried over again in broiler for twenty-four $\mathrm{h}$ and a comparable technique modified into pursued until the aim variety changed into completed. This gauged without a doubt nicely honestly
This take a look at is performed to evaluate the character of

really worth modified into named as variety dry weight (A). At that difficulty the examples had been saved in water of temperature $21^{\circ} \mathrm{C}$ for $48 \mathrm{~h}$ and gauged. The examples were then stored in water for twenty-four $\mathrm{h}$ more and gauged.

The progressive gauged values for exams were looked at and if the honestly surely well worth indicated over $0.5 \%$ range, the examples were saved all over again in water for twenty-four $\mathrm{h}$ and a comparable technique changed into pursued till the goal augmentation have emerge as finished. This changed into named as surface dried weight (B).

Water ingestion after inundation in $\%=[(\mathrm{B}-\mathrm{An}) / \mathrm{A}] * 100$ in which, $\mathrm{A}=$ Oven dry weight

$\mathrm{B}=$ floor dry weight

Four.4 Acid assault test

A few substance conditions can collapse the mortar no matter whether or not or now not or no longer it is a terrific extremely good mortar. Sulphuric corrosive may be framed through the use of sulfurous gases which systems at some point of ignition response with dampness and systems sulphuric corrosive. Moreover, the microscopic organisms present inside the sewage modifications over in to sulphuric corrosive. To direct the corrosive assault take a look at, three examples of blocks $70.6 \mathrm{~mm} \times 70.6 \mathrm{~mm} \times 70.6 \mathrm{~mm}$ next to restoring had been taken. The underlying masses of the three-D squares in advance than inundating within the affiliation is said. Examples had been submerged within the affiliation of $5 \%$ of sulphuric corrosive. The $\mathrm{pH}$ of three modified into stored up at a few degree inside the take a look at. Following 28 and 56 days, examples want to preserve for 1 day for drying. In the wake of drying, take a look at the heaviness of the examples and moreover the compressive tremendous of the examples with the beneficial resource of trying out it in compressive attempting out device. Endure in mind the decrement of masses and compressive awesome with normal cement.

\section{Four.Five Sulphate assault take a look at}

Sulfate assault can rise up specially processes interior and outer assaults. Outer sulfate assault can upward push up through conditions like soil, water which enters to strong systems. Indoors sulfate attack can seem each thru way of excessive sulfate content material cloth or from totals debased with gypsum. Ettringite affiliation will seem even as sulfate responds with hydrated mixes in cement and it turns on improvement and results in breaking and spalling of cement. The examples in the wake of restoring had been gauged and mentioned due to the reality the underlying load of the examples. At that component, the examples have been submerged inside the $5 \%$ of sodium sulfate association. Following 28, fifty six and 90 days, examples had been taken out from the association and permit it to dry. Test the heaviness of the example as conclusive estimations of examples. Moreover, the compressive wonderful and comparison it and starting compressive outstanding.

\section{6 speedy chloride infiltration check}

In this take a look at, the chloride particle the front is tried via the use of passing present day-day-day. The method for 
the RCPT test is given in ASTM C 1202.It suggests the obstruction of cement to chloride particle the front. The chamber is reduce into the plate chambers of $50 \mathrm{~mm}$ utilising reducing tool. At that point the example's horizontal facet is included with epoxy gum and rest it for dry. Examples are saved in vacuum chamber for three hours and in a while soaked it with water. From that detail in advance, the examples are embedded into the cells and seal it tight utilising epoxy sap so it is going to be water tight and hold it for inside the destiny for drying. One mobile is associated with cathode terminal that is recorded with $3 \%$ of sodium chloride arrangement. One in every of a kind cell is related to anode loaded up with zero. $3 \mathrm{~N}$ of sodium hydroxide affiliation. Examples are exposed to $60 \mathrm{~V}$ ability continuously for 6 hours. Current-day and temperature readings being anticipated in each 15

Minutes, from which absolute charge handed is determined.

\section{RESULTS AND DISCUSSION}

\section{five.1 Ultrasonic Pulse pace take a look at (UPV)}

Ultrasonic trying out of mortar or ultrasonic heartbeat velocity take a look at on mortar block is a non-ruinous check to survey the homogeneity and uprightness of mortar. With this ultrasonic take a look at on mortar any irregularity in move phase like breaks and profundity of surface splits may be resolved.

Table-3 Ultrasonic Pulse Velocity values

\begin{tabular}{|c|c|c|c|}
\hline $\begin{array}{c}\text { Control } \\
(\mathrm{m} / \mathrm{sec})\end{array}$ & $\begin{array}{c}20 \% \\
\text { GGBS } \\
(\mathrm{m} / \mathrm{sec})\end{array}$ & $\begin{array}{c}40 \% \\
\text { GGBS } \\
(\mathrm{m} / \mathrm{sec})\end{array}$ & $\begin{array}{c}60 \% \\
\text { GGB } \\
\mathrm{S} \\
(\mathrm{m} / \mathrm{sec} \\
\end{array}$ \\
\hline 3812 & 3765 & 3886 & 3945 \\
\hline
\end{tabular}

The UPV test has been conducted on cube samples and mean values has been provided in Table-3. As the Ultrasonic pulse velocity values are between $3500-4000 \mathrm{~m} / \mathrm{sec}$ the mortar cubes are graded as good quality mortars.

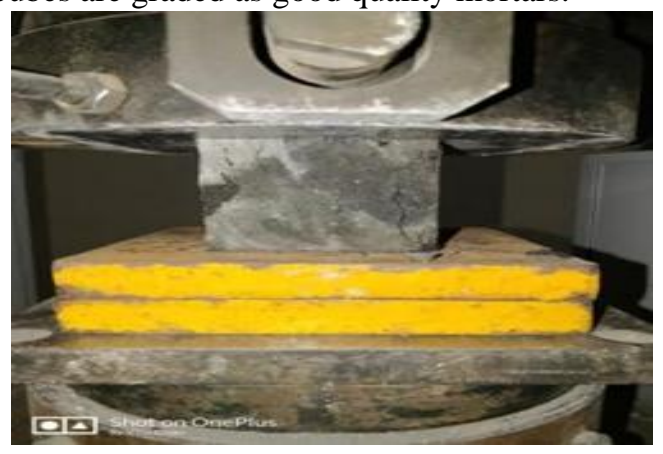

Fig.5 Compression testing

\subsection{Tensile Strength Test}

The tensile strength of cement mortar is determined by casting of samples in the specified briquette moulds as per ASTM-C-190. After the mortar has been set it is been water cured. The testing has been done on 7 and 28 days. The load is to be applied at a uniformed rate of $35 \mathrm{~kg} / \mathrm{cm}^{2}$. thickness and $100 \mathrm{~mm}$ thickness distance inside the course of

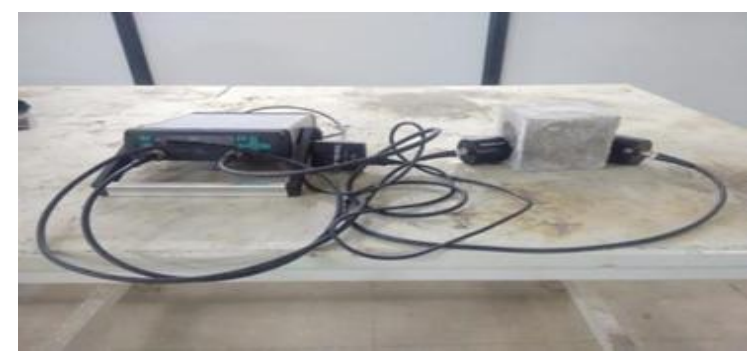

Fig.3 UPV Instrument

5.2 Compressive Strength Test

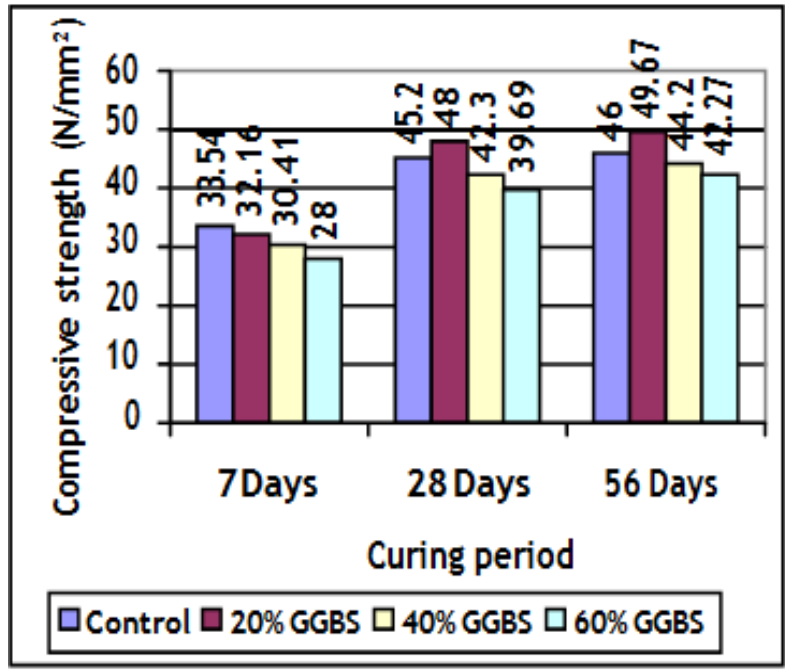

Fig.4 Compressive Strength

The compressive strength of Control mix is high than that of the compressive strength of others at 7 days test. This is due to the rate of hydration. But at 28 days test it is noticed that $20 \%$ GGBS mix had more compressive strength than the control mix. As days passes the strength is considerably increased comparing to control mix.

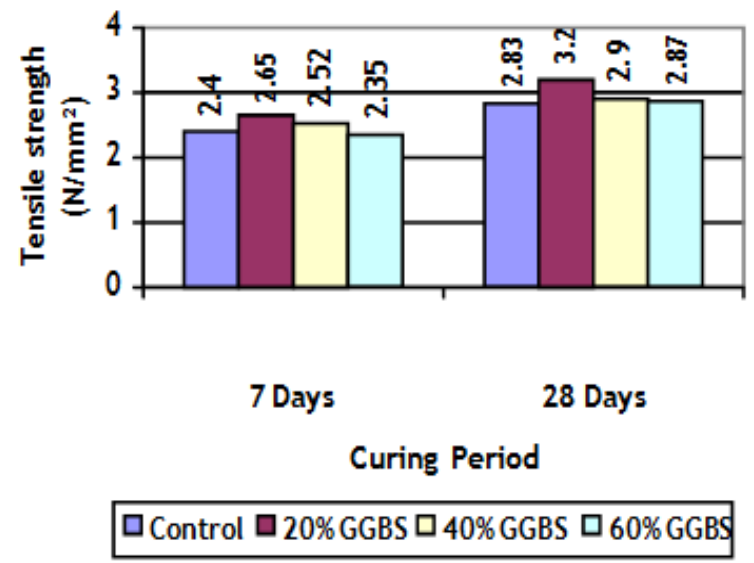

Fig.6 Tensile Strength

From the arrived tensile strength values it can be noted that the $20 \%$ GGBS mix has performed well at both 7 and 28 days than that of the Control mix .

\subsection{Water Absorption Test}

The sample specimens for water absorption test has been cured for 7 and 28 days. Then the samples has been oven

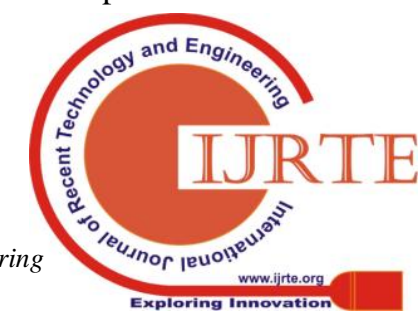


International Journal of Recent Technology and Engineering (IJRTE) ISSN: 2277-3878, Volume-8, Issue-2S11, September 2019

dried and later surface dried. So the Oven dried weight (A) and Surface dried weight (B) has been obtained with this the percentage of water absorption by the mortar is determined.

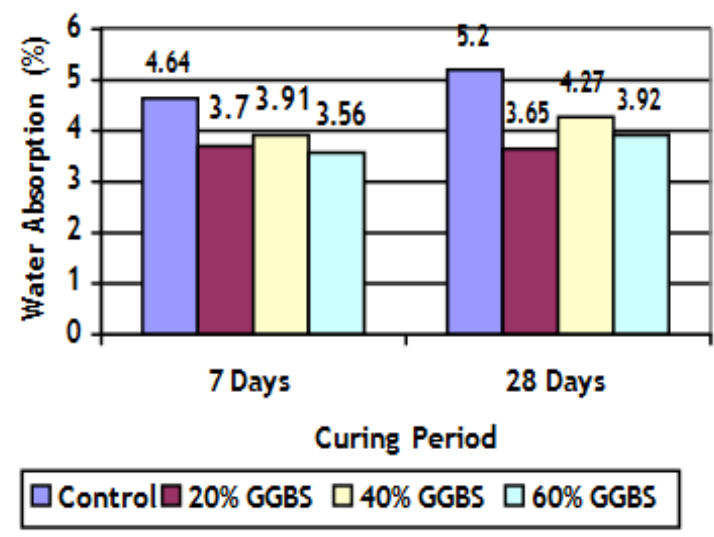

Fig.7 Water Absorption

\subsection{Acid Attack Test}

The samples kept in sulfuric acid were checked for weight and compressive strength. It's noticed that there is a change in weight as the outer layer gets degraded. Also, there is a decrease in the compressive strength of the sample as compared to the initial strength.

Table-4 Compressive Strength (Acid Attack)

\begin{tabular}{|c|c|c|c|c|}
\hline \multirow{2}{*}{ Description } & \multicolumn{4}{|c|}{ Compressive Strength (N/mm $\left.{ }^{2}\right)$} \\
\cline { 2 - 5 } & Control & $\begin{array}{c}20 \% \\
\text { GGBS }\end{array}$ & $\begin{array}{c}40 \% \\
\text { GGBS }\end{array}$ & $\begin{array}{c}60 \% \\
\text { GGBS }\end{array}$ \\
\hline 28 Days & 42.28 & 44.86 & 39.5 & 36.4 \\
\hline 56 Days & 39.4 & 41.35 & 36.81 & 33.1 \\
\hline
\end{tabular}

Table-5 Change in weight

\begin{tabular}{|c|c|c|c|c|}
\hline \multirow{2}{*}{ Description } & \multicolumn{4}{|c|}{ Change in weight (\%) } \\
\cline { 2 - 5 } & Control & $\begin{array}{c}20 \% \\
\text { GGBS }\end{array}$ & $\begin{array}{c}40 \% \\
\text { GGBS }\end{array}$ & $\begin{array}{c}60 \% \\
\text { GGBS }\end{array}$ \\
\hline 28 Days & 2.3 & 2.25 & 2.4 & 2.45 \\
\hline 56 Days & 5.2 & 5.3 & 5.6 & 5.5 \\
\hline
\end{tabular}

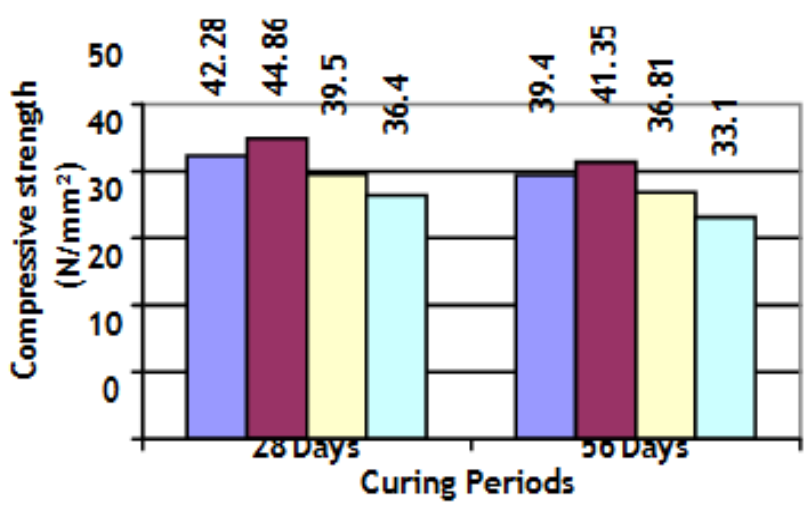

\section{$\square$ Control $\square$ 20\% GGBS $\square$ 40\% GGBS $\square$ 60\% GGBS}

Fig.8 Compressive strength (Acid Attack)

\subsection{Sulphate Attack Test}

The samples kept in sodium sulphate were checked for weight and compressive strength. Sodium sulphate reacts and there will be disruption of cement paste that leads to loss in strength and cohesion.
Table-6 Compressive strength (Sulphate Attack)

\begin{tabular}{|c|c|c|c|c|}
\hline \multirow{2}{*}{ Description } & \multicolumn{4}{|c|}{ Compressive Strength $\left(\mathrm{N} / \mathrm{mm}^{2}\right)$} \\
\cline { 2 - 5 } & Control & $\begin{array}{c}20 \% \\
\text { GGBS }\end{array}$ & $\begin{array}{c}40 \% \\
\text { GGBS }\end{array}$ & $\begin{array}{c}60 \% \\
\text { GGBS }\end{array}$ \\
\hline 28 Days & 43.32 & 45.6 & 40.3 & 36.25 \\
\hline 56 Days & 41.2 & 44.34 & 37.8 & 34.5 \\
\hline
\end{tabular}

Table-7 Change in weight

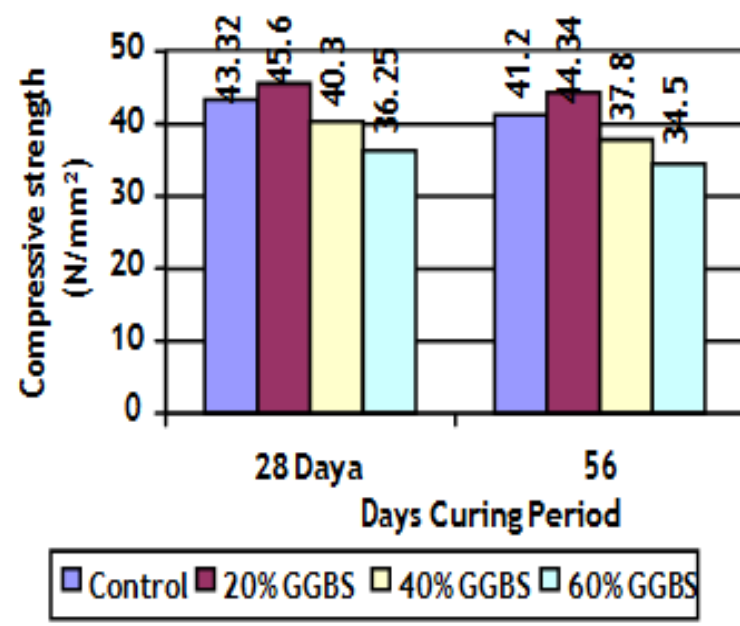

Fig.9 Compressive strength (Sulphate Attack)

\subsection{Rapid Chloride Penetration Test (RCPT)}

Rapid Chloride Penetration apparatus consist of two cells. One cell is connected to cathode terminal that is filed with $3 \%$ of sodium chloride solution. Other cell is connected to anode filled with $0.3 \mathrm{~N}$ of sodium hydroxide solution. Specimens are subjected to $60 \mathrm{~V}$ Potential continuously for 6 hours.

Table-8 Rapid Chloride Penetration values

\begin{tabular}{|c|c|c|c|c|}
\hline Description & Control & $\begin{array}{c}20 \% \\
\text { GGBS }\end{array}$ & $\begin{array}{c}40 \% \\
\text { GGBS }\end{array}$ & $\begin{array}{c}60 \% \\
\text { GGBS }\end{array}$ \\
\hline 28 Days & 890 & 1312 & 1250 & 1264 \\
\hline 56 Days & 765 & 1251 & 1195 & 1170 \\
\hline
\end{tabular}

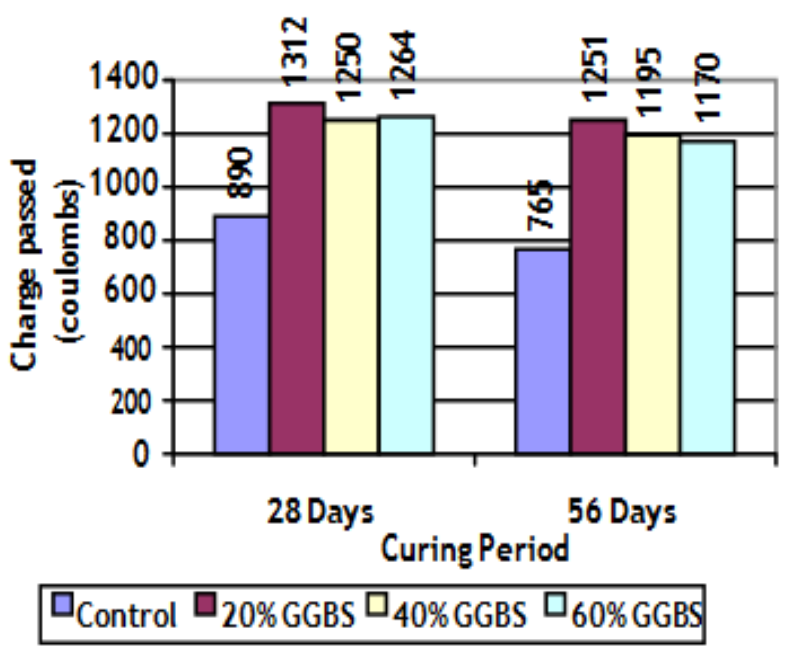

Fig-10 RCPT Values

Published By: 
Table-9 Chloride Permeability Based on Charge Passed

\begin{tabular}{|c|c|}
\hline $\begin{array}{c}\text { Charges Passed } \\
\text { (coulombs) }\end{array}$ & $\begin{array}{c}\text { Chloride Ion } \\
\text { Penetration }\end{array}$ \\
\hline$>4000$ & High \\
\hline $2000-4000$ & Moderate \\
\hline $1000-2000$ & Low \\
\hline $100-1000$ & Very low \\
\hline$<100$ & Negligible \\
\hline
\end{tabular}

The effects show that the examples are impervious to chloride particle the front, wherein the control mortar is secure with the beauty of quite low and the

Considered one of a kind mortar aggregate amount are low.

\section{VI.CEASE}

1. The vital detail of this exploration is to decorate the trademark high-quality of mortar, supplanted with $0 \%, 20$, $40 \%$ and $60 \%$ of ground-granulated effect heater slag to the concrete and find out the proper rate substitution.

2 . In view of the effects had been given from the analyses the ensuing ends have been inferred with understand to the exhibition of the mortar.

3. The GGBS fused mortar carried on advanced to the ordinary mortar in every mechanical and solidness component of view.

4. The compressive satisfactory of control mixture is more than some different combination on 7 th day take a look at. That is due to the tempo of hydration.

5 . The $20 \%$ GGBS mixture mortar has finished nicely at some level inside the twenty 8 th day stress check.

6. 40\% GGBS combination mortar carried on in a comparative fasion as that of the control mortar.

7. The tension take a look at demonstrates that the $20 \%$ GGBS combination mortar finished well than a few extraordinary blends.

8. $60 \%$ GGBS aggregate mortar has low water ingestion than a few precise aggregate.

9. In every Acid and Sulfate attack check $20 \%$ GGBS combination has finished well with less weakening and weight loss.

10. The fee went in RCPT is among a thousand-2000 for the GGBS mortars in order that they fall beneath the magnificence of Low and the common mortar is going under Very low elegance.

11. Subsequent to contemplating each one of the effects the $20 \%$ and forty $\%$ GGBS mortar have finished nicely contrasting with the common mortar. The $60 \%$ GGBS combination mortar requires more days to carry out the incredible of ordinary mortar. Thinking about the herbal impact due to the Cement through techniques for $\mathrm{CO}_{2}$ outflow some substitution have to be finished. Alongside those strains, GGBS is probably the first-rate alternate for bond. $20-40 \%$ substitution of GGBS to concrete is proposed

\section{REFERENCES}

1. Rami A. Hawileh, Jamal A. Abdalla, Fakherdine Fardmanesh, Poya Shahsana, Abdolreza Khalili (2017). Execution of fortified sturdy bars sturdy with numerous costs of GGBS substitution to concrete. Documents of common and mechanical engineering17 ( 2017) 511-519.

2. A. Oner, S. Akyuz (2007). An exploratory examination on super use of GGBS for the compressive high-quality of cement. Bond and urban Composites 29 (2007) 505-514.

3. Ardra Mohan, right enough.M. Smaller than normal (2018). Wonderful and sturdiness investigations of SCC consolidating silica smoke and extremely excellent GGBS. Improvement and building substances 171 (2018) 919-928.

4. S. Krishna Rao , P. Sravana , T. Chandrasekhar Rao (2016). Scraped location competition and mechanical houses of roller Compacted Concrete withGGBS. Improvement and building substances 114 (2016) 925-933.

5. Vireen Limbachiya , Eshmaiel Ganjian, Peter Claisse (2016). Amazing, sturdiness and draining houses of sturdy clearing squares becoming a member of GGBS and SF. Improvement and constructing substances 113 (2016) 273-279.

6. Okay. Ganesh Babu, V. Sree Rama Kumar (2010). Effectiveness of GGBS in concrete. Bond and concrete studies 30 (2010) 1031-1036.

7. S. Vijaya Bhaskar Reddy, Dr.P.Srinivasa Rao (2016). Test thinks about on compressive tremendous of ternary blended cements at diverse stages of small scale silica and GGBS. Substances these days: lawsuits 3 (2016) 3752-3760

8. J. Vijayaraghavan, A. Belin Jude (2017). Effect of copper slag, iron slag and reused strong preferred at the mechanical homes of cement. Property insurance fifty three (2017) 219-225.

9. Rahul Sharma, Rizwan A. Khan (2018). Effect of copper slag and metakaolin at the sturdiness of self compacting concrete. Diary of purifier production 171 (2018) 1171-1186

10. Wei Wu, Weide Zhang (2010). Perfect substance of copper slag as a exquisite preferred in immoderate first-rate cement. Materials and layout 31 (2010) 2878-2883.

11. M.S. Muhd Norhasri, M.S. Hamidah, A. Mohd Fadzil (2017). Uses of utilising nano fabric in concrete:A audit. Improvement and constructing substances, Vol.133, pp 91-ninety seven

12. Mosad Mohamed Sadawy and EltohamyRabie Elsharkawy (2016). Effect of Nano-Tio2addition on Mechanical houses of Concrete and Corrosion behavior of Reinforcement Bars. Int. Diary of Engineering studies and application ISSN : 2248-9622, Vol. 6, trouble 10, (detail 1)

13. Rahul Sharma, Rizwan A. Khan (2017). Longevity assessment of self compacting cement becoming a member of copper slag as exquisite totals. Improvement and constructing materials 155 (2017) 617-629.

14. Khalifa S. Al-Jabri, Makoto Hisada (2009). Copper slag as sand substitution for elite cement. Bond and concrete Composites 31 (2009) 483-488.

15. IS 12269-1987.,Indian substantial power of will for 53 grade not unusual Portland concrete, Bureau of Indian requirements, New Delhi, 1997.

16. IS 4031-6 (1988). Guarantee of compressive superb of hydrated bond ,New Delhi. 